\title{
Nontraditional Risk Factors for Obesity in Modern Society
}

\author{
Su-Jin Han', Seung-Hwan Lee ${ }^{1,2, *}$ \\ 'Division of Endocrinology and Metabolism, Department of Internal Medicine, Seoul St. Mary's Hospital, College of Medicine, The Catholic University of Korea, Seoul; \\ ${ }^{2}$ Department of Medical Informatics, College of Medicine, The Catholic University of Korea, Seoul, Korea
}

Overweight and obesity, which have rapidly increased around the world in recent years, are significant health problems. They can lead to various morbidities, including cardiovascular diseases, cerebrovascular diseases, type 2 diabetes, some types of cancer, and even death. Obesity is caused by an energy imbalance due to excessive calorie intake and insufficient energy consumption, and genetic factors and individual behavioral problems are also known to be major contributing factors. However, these are insufficient to explain the surge in obesity that has occurred in recent decades. Recent studies have suggested that environmental factors arising from the process of socioeconomic development and modernization contribute to this phenomenon. These environmental factors include light pollution due to artificial lighting, air pollution, endocrine-disrupting chemicals, and reduced exposure to green spaces due to urbanization of residential areas. In this manuscript, the findings and mechanisms of these novel risk factors causing overweight and obesity are reviewed.

Key words: Obesity, Risk factors, Environmental pollution, Endocrine disruptors
Received January 15, 2021

Reviewed February 16, 2021

Accepted February 18, 2021

${ }^{*}$ Corresponding author

Seung-Hwan Lee

(iD)

https://orcid.org/0000-0002-3964-3877

Division of Endocrinology and Metabolism, Department of Internal Medicine, Seoul St. Mary's Hospital, College of Medicine, The Catholic University of Korea, 222 Banpo-daero, Seocho-gu, Seoul 06591, Korea Tel: +82-2-2258-6069

Fax: +82-2-595-2534

E-mail: hwanx2@catholic.ac.kr

\section{INTRODUCTION}

Overweight and obesity are among the most important health problems facing modern society worldwide. The World Health Organization (WHO) reported in 2016 that more than 1.9 billion adults (18 years and older) were overweight; of these, more than 650 million adults had obesity. ${ }^{1}$ This figure means that $39 \%$ of adults were overweight and $13 \%$ obese. In fact, the worldwide prevalence of obesity nearly tripled between 1975 and 2016. ${ }^{1}$ Similarly, the prevalence of obesity in Korea has increased by 6\% (from $32.6 \%$ to $38.5 \%$ ) in the last 10 years. ${ }^{2}$ Currently, overweight and obesity are associated with more deaths than malnutrition and underweight in all parts of the world except for sub-Saharan Africa and Asia. ${ }^{1}$
Obesity has become a global health problem beyond individual health concerns because it is closely associated with the increased prevalence of chronic diseases, such as high blood pressure, dyslipidemia, coronary heart disease, stroke, type 2 diabetes, and some types of cancer. ${ }^{3}$ Obesity appears as fat accumulation from high caloric intake and insufficient energy consumption, and many studies have shown that genetic factors and personal behavior play important roles as causes of obesity. ${ }^{47}$ However, this is insufficient to fully explain the surge in overweight and obese populations in recent decades. Economic and social development and the urbanization of residential areas have brought about positive effects in modern society, such as convenience of living and affluent life, but detrimental results also exist. Accompanying negative effects include reduced physical activity, increased environmental pollution, com-

Copyright (C) 2021 Korean Society for the Study of Obesity

(a) This is an Open Access article distributed under the terms of the Creative Commons Attribution Non-Commercial License (https://creativecommons.org/licenses/by-nc/4.o/) which permits unrestricted non-commercial use, distribution, and reproduction in any medium, provided the original work is properly cited. 
plex surroundings, and increased stress. Because studies have suggested that novel environmental factors in modern society may have caused the recent surge in obesity, these studies and their evidence are reviewed.

\section{DISRUPTION OF CIRCADIAN RHYTHM AND LIGHT POLLUTION}

Almost all living organisms have a self-regulating transcriptionaltranslational feedback loop that generates oscillations in a period of approximately 24 hours. This endogenous timekeeping mechanism is called a circadian clock. ${ }^{6}$ The circadian clock controls many aspects of an organism's physiology and is affected by external stimuli, such as light, food, and temperature. ${ }^{8,9}$ The main function of the circadian clock/rhythm is to maintain homeostasis by ensuring adaptive physiological responses to changing environments. For example, gene expression, transcription factors, signaling pathways, hormone secretion, energy metabolism, growth, and behavior are rhythmically regulated by the circadian system. ${ }^{10,11}$ Therefore, disturbance of the circadian rhythm has a long-term effect on health and may be associated with the development of obesity in relation to lipid metabolism. ${ }^{12}$ The main component of the circadian system in mammals is located in the suprachiasmatic nucleus (SCN) of the hypothalamus and consists of more than 20,000 neurons. The SCN interacts with peripheral circadian clocks, such as the heart, liver, stomach, adipose tissue, and pancreas. ${ }^{13}$

Various hormones, such as melatonin, leptin, and glucocorticoids, have a light-dark cycle and are involved in the regulation of feeding, lipid metabolism, and fat accumulation. ${ }^{14,15}$ Melatonin is a pineal hormone synthesized at high levels during the night and at low levels during the day according to circadian patterns, ${ }^{16}$ and its role in lipid metabolism has been widely reported. For example, in studies using mice, knockout of the melatonin receptor led to systemic insulin resistance, and these mice showed more fat mass, weight gain, and leptin resistance. ${ }^{17,18}$ Leptin is mainly synthesized and secreted by white adipose tissue and peaks during the sleep phase in diurnal animals, such as humans, and during early to midnight in nocturnal animals, such as mice. ${ }^{19}$ Leptin plays an important role in food intake, energy expenditure, lipid metabolism, and insulin sensitization, ${ }^{20,21}$ and leptin resistance in obese people is as- sociated with obesity and metabolic disease due to circadian dysfunction. ${ }^{22}$ Glucocorticoids are regulated through the hypothalamus-pituitary-adrenal axis, and blood levels peak before the active phase (early morning) in humans. ${ }^{23}$ Glucocorticoids are involved in lipid and glucose metabolism, and high concentrations of glucocorticoids are generally observed in obesity. ${ }^{24}$

Recently, artificial light at night (ALAN) has been suggested as an environmental factor that induces obesity. The invention of electricity enabled activities without distinction between day and night, resulting in positive effects, such as convenient life and social and economic development. ${ }^{25}$ However, it has also caused exposure to ALAN, such as indoor lighting, road lighting, store signs, television screens, and smartphone and tablet devices used before bedtime or during sleeping. Because most organisms have developed endogenous circadian rhythms that are synchronized to the daily light/dark cycle, exposure to ALAN may disrupt the circadian rhythm and alter the secretion pattern of various hormones, leading to metabolic diseases, including obesity. ${ }^{26}$

Animal studies have provided evidence that exposure to artificial lighting can directly affect circadian rhythms, resulting in weight gain and obesity. Fonken et al. ${ }^{27}$ exposed mice to complete darkness or dim light during the night and found that exposure to dim light at night altered circadian clock genes and protein rhythms, changed feeding behavior, and led to rapid and sustained body weight gain. There was no difference in total daily caloric intake between the two groups, but mice exposed to dim light at night consumed more food during the light period and less food during the dark period than mice housed on dark nights. Both the central clock rhythm (the amplitude of Per1 and Per2 rhythms was attenuated in the hypothalamus) and the peripheral clock rhythm (Rev-Erb expression was attenuated in the liver and adipose tissue) were altered in mice exposed to dim light at night. Similar results were found in human studies. An analysis using satellite images of nighttime illumination combined with country-level data on the prevalence of overweight and obesity showed that ALAN is a significant contributing factor to excessive body mass. ${ }^{28}$ Zhang et al. ${ }^{29}$ also showed that higher outdoor light at night, estimated from satellite imagery, is associated with higher odds ( $12 \%$ in men and 19\% in women when the highest quintile group was compared with the lowest quintile group) of developing obesity over 10 years in non-obese American adults. 
Park et al. ${ }^{30}$ investigated the relationship between ALAN exposure during sleeping and the prevalence and risk of obesity in women aged 35 to 74 years old recruited in 50 U.S. states and Puerto Rico from 2004 through 2009. ALAN was categorized as no light, small nightlight in the room, light outside the room, or light or television in the room. At baseline, having any ALAN exposure was positively associated with a higher prevalence of obesity and abdominal obesity. Furthermore, turning on the television or turning on the light in the room while sleeping was associated with a weight gain of $5 \mathrm{~kg}$ or more (relative risk [RR], 1.17; 95\% confidence interval [CI], $1.08-1.27)$, body mass index (BMI) increase of $10 \%$ or more (RR, 1.13 ; 95\% CI, 1.02-1.26), incident overweight (RR, 1.22; 95\% CI, 1.06-1.40), and incident obesity (RR, 1.33; 95\% CI, 1.13-1.57) compared to cases without ALAN exposure. These data suggest possible contribution of ALAN in the development or aggravation of obesity, and further studies on its precise mechanisms are warranted.

\section{ENVIRONMENTAL POLLUTION AND PARTICULATE MATTER}

Environmental pollution, which increases with industrialization, is reaching a level that threatens human health. In fact, it has been reported that 4.2 million people die per year as a result of exposure to fine particulate matter (PM). ${ }^{31} \mathrm{PM}$ is one of the major air pollutants. Particles with a diameter of $10 \mu \mathrm{m}$ or less are classified into particulate matter $\left(\mathrm{PM}_{10}\right)$, and those with a diameter of less than $2.5 \mu \mathrm{m}$ are classified into fine particulate matter $\left(\mathrm{PM}_{2.5}\right){ }^{32} \mathrm{PM}$ is known to contain various chemical components, such as nitrates, sulfates, and polycyclic aromatic hydrocarbons, as well as endotoxins, cell fragments, and various metal components. ${ }^{33} \mathrm{PM}_{2.5}$ can enter cells more easily than $\mathrm{PM}_{10}$ due to its smaller size, and $\mathrm{PM}_{2.5}$ entering the respiratory tract can therefore affect other tissues, such as the cardiovascular system and gastrointestinal system. The most commonly known mechanism of disease induction by PM is cytotoxicity caused by oxidative stress. PM entering the respiratory tract promotes the generation of active radicals, causing oxidative stress in lung tissue and activating intracellular stress signaling molecules, such as p53 and c-Jun N-terminal kinase (JNK), and transcription factors, such as nuclear factor kappa B (NF-kB) and activator pro- tein 1 (AP-1). It also induces the expression of inflammatory cytokines, such as interleukin (IL)-1 and IL-6. These increased inflammatory cytokines promote cytotoxicity in tissues exposed to PM and induce various diseases. ${ }^{34,35}$

Recently, studies on the effect of $\mathrm{PM}_{2.5}$ on metabolic diseases have emerged. Continuous exposure to PM is known to increase the local inflammatory response, hepatic endoplasmic reticulum stress, and insulin resistance. ${ }^{36,37}$ In animal experiments, long-term exposure to $\mathrm{PM}_{2.5}$ has been shown to activate the transcription factor NF-кB-related inflammatory protein complex, increase insulin resistance, ${ }^{38}$ and induce macrophage infiltration and lipid deposition in white adipose tissue. ${ }^{39}$ The hypothalamus maintains energy homeostasis by synthesizing nerves and regulating nutritional and hormonal signals. In particular, leptin receptor-expressing neurons in the hypothalamus nuclei are important for regulating food intake and energy expenditure, and leptin signaling through proopiomelanocortin (POMC) neurons promotes anorexigenic effects while increasing energy expenditure. ${ }^{40,41}$ Toll-like receptor 4 (TLR4) contributes to insulin resistance and obesity, which activates signaling pathways of the inhibitor of NF- $\kappa B$ kinase subunit beta and NF- $\kappa B$ transcription factor. Thus, it increases the expression of proinflammatory genes. ${ }^{42,43}$ Campolim et al. ${ }^{44}$ investigated whether a reaction similar to the metabolic effect of a high-fat diet appeared when exposed to $\mathrm{PM}_{2.5}$ in mice fed a chow diet. Compared to the filtered air group, the group exposed to $\mathrm{PM}_{2.5}$ for 5 days had increased microglial density and expression of TLR4 and inhibitor-NF-KBkinase-epsilon (Ikbke); meanwhile, the amount of fat and food intake increased. In addition, in the group exposed to $\mathrm{PM}_{2.5}$ for 12 weeks, decreased hypothalamic STAT3 phosphorylation and POMC expression were found, which were accompanied by increased food intake and low energy expenditure, leading to obesity along with increased leptin resistance and insulin resistance. In a rodent model, exposure to Beijing's highly polluted air was associated with more weight gain in pregnant rats and their offspring. ${ }^{45}$

Deschenes et al. ${ }^{46}$ analyzed the relationship between air pollution and body weight in China using data from the China Health and Nutrition Survey. As a result of the analysis of 13,471 adults, when the average $\mathrm{PM}_{2.5}$ concentration increased by $1 \mu \mathrm{g} / \mathrm{m}^{3}$ over the previous 12 months, the $\mathrm{BMI}$ increased by $0.27 \%$, and there were increases in overweight and obesity rates by $0.82 \%$ and $0.27 \%$, respec- 
tively. A study consisting of 41,439 schoolchildren from China demonstrated that the obesity risk increased by $10 \%$ per $10 \mu \mathrm{g} / \mathrm{m}^{3}$ increase in $\mathrm{PM}_{2.5}$ exposure. ${ }^{47} \mathrm{~A}$ longitudinal study in overweight and obese Latino children investigated the association of exposure to nitrogen dioxide or $\mathrm{PM}_{2.5}$ with adiposity, and concluded that both pollutants induced more rapid increases in $\mathrm{BMI}$ and central adiposity. A $4 \mu \mathrm{g} / \mathrm{m}^{3}$ difference in long-term $\mathrm{PM}_{2.5}$ was associated with a $3 \mathrm{~kg} / \mathrm{m}^{2}$ higher BMI and a $2 \%$ higher body fat percentage at age 18 years. ${ }^{48}$ Another Chinese study from a high pollution area showed that a $19 \mu \mathrm{g} / \mathrm{m}^{3}$ increase of $\mathrm{PM}_{10}$ was also associated with increased prevalence of overweight (8\%) and obesity (12\%), which were more apparent in women than in men. ${ }^{49}$ However, a systematic review including 16 human studies suggested mixed results. Among a total of 66 reported associations between air pollution and weight status, $44 \%$ found a positive association, and $44 \%$ reported a null finding. ${ }^{50}$ Therefore, well-designed prospective studies should be performed in various populations in the future.

\section{ENDOCRINE-DISRUPTING CHEMICALS}

Evidence suggests that interactions between environmental factors and genetic factors can lead to acquired obesity. ${ }^{51,52}$ Endocrinedisrupting chemicals (EDC) are defined by the $\mathrm{WHO}$ as "exogenous chemicals or mixtures of chemicals that alter the function(s) of the endocrine system and consequently cause adverse health effects in an intact organism, its progeny, or (sub)populations." Recent studies have shown that some of them are obesogenic by inducing altered epigenetic gene regulation. ${ }^{53-55} \mathrm{EDC}$ can occur naturally, such as plant estrogens, but they penetrate deeply into daily life in the form of synthetic compounds, such as pesticides, detergents, food packaging materials, internal coatings for metal cans, various plastic products, and thermal receipts. The human body is easily exposed to EDC through ingestion of contaminated water and food, inhalation, and skin contact. Even a small dose can have a strong effect and cause effects decades after exposure or even in descendants. ${ }^{56}$

EDC causes obesity and related metabolic diseases by binding to or interfering with hormone receptors, disrupting the homeostasis system in the body and the metabolism of lipid tissues with hormone receptors. ${ }^{57,58} \mathrm{EDC}$ is mostly lipophilic and can be stored in adipocytes for a long time. The number of adipocytes produced during early development is permanently established, and weight gain in adults occurs due to an increase in the size of existing adipocytes. ${ }^{59}$ In addition, early lifetime EDC exposure affects epigenetic programming of obesity by activating or inhibiting nuclear receptors and the expression of target genes, creating a permanently increased number of adipocytes and altered metabolic set points. This increases the potential risk for obesity and metabolic diseases. ${ }^{60,61}$

Peroxisome proliferator-activated receptor- $\gamma$ (PPAR $\gamma)$ is highly expressed in adipose tissue and is a key molecule that regulates adipogenesis. It regulates triglyceride accumulation, glucose metabolism, and insulin sensitivity in mature adipocytes as well as differentiation into adipocytes. ${ }^{62} \mathrm{EDC}$ acts as a ligand for PPAR $\gamma$, mutating DNA methylation of PPAR $\gamma$ or its target genes. ${ }^{63,64}$ Therefore, in a process that relies on binding to PPAR $\gamma$ with relative regulation of the PPAR $\gamma$-inducing gene, mesenchymal stem cells can be preferentially introduced toward differentiation into adipocytes, potentially promoting the development of adipose tissue during early development. In addition to binding to PPAR $\gamma$, EDC promotes provincial cell differentiation through a variety of regulatory pathways, including agonistic effects on estrogen, glucocorticoid, and aryl hydrocarbon receptors. ${ }^{65,66} \mathrm{EDC}$, referred to as an obesogen, includes tributyltin, diethylstilboestrol, persistent organochlorine, bisphenol A (BPA), and phthalates. In particular, BPA and phthalate exposure can easily occur in daily life. ${ }^{67,68}$

BPA is a lipophilic molecule with estrogen activity that accumulates in adipose tissue and interferes with the adipose tissue differentiation mechanism. As a material for producing epoxy resin and polycarbonate plastic, it is used in baby bottles, the inside coat of cans, food containers, and dental treatment materials and the human body is easily exposed through oral ingestion. ${ }^{69}$ Evidence suggests that exposure to BPA is associated with obesity in animal and human experiments. In animal experiments, Rubin et al. ${ }^{70}$ found that Sprague-Dawley rats with perinatal exposure to BPA exhibited apparent weight gain immediately after birth and continued to gain weight until adulthood. In humans, BPA was shown to inhibit the release of adiponectin from adipose tissue, which is known to lower the likelihood of obesity-related diseases. ${ }^{71}$ Carwile and Michels ${ }^{72}$ analyzed the association between urinary BPA and BMI and waist circumference (WC) using data from the National Health and $\mathrm{Nu}$ - 
trition Examination Survey (NHANES) 2003-2006 and concluded that high BPA exposure is related to general and central obesity in adults.

Phthalates are used to increase the flexibility of plastic products; they are used in children's toys, food packing, medical devices, shampoos, and cosmetics. The human body is easily exposed to them through skin absorption, inhalation, or ingestion of contaminated materials. ${ }^{73}$ Several in vivo and in vitro studies have shown that phthalates can promote obesity through anti-androgen effects, anti-thyroid hormone activity, and activation of PPARs. ${ }^{74-77}$ Studies have also analyzed the cross-sectional relationship between phthalates and obesity in humans based on data from NHANES in the United States. Stahlhut et al. ${ }^{78}$ demonstrated that urinary monoethyl phthalate (MEP), monobenzyl phthalate, mono(2-ethyl-5-hydroxyhexyl) phthalate (MEHHP), and mono(2-ethyl-5-oxohexyl) phthalate had positive correlations with WC in adult men. There was a positive correlation between female urinary MEP, monobutyl phthalate, MEHHP and BMI or WC. ${ }^{79,80}$ A recent study based on the data of NHANES 2007-2010 found that high molecular weight phthalate was associated with an increased risk of obesity in adult men, while di(2-ethylhexyl) phthalate was associated with increased obesity in women. ${ }^{81}$

\section{REDUCED GREEN SPACE}

Urbanization of residential environments reduces the chances of human contact with green spaces, and accumulating evidence suggests that changes in the built environment may be related to obesity. In this regard, exposure to green spaces around residential areas (accessibility and availability of areas with vegetation, such as parks, gardens, and forests) has attracted more attention in recent years. ${ }^{82,83}$ The exact mechanism for the association between green spaces and obesity is not yet known, but several hypotheses have been proposed regarding the pathophysiological pathway of obesity. ${ }^{84,85}$ First, living close to green space increases opportunities and motivation for physical activity, and increases in physical activity can act as a strong protective factor against obesity ${ }^{86}$ Second, high levels of stress can lead to obesity ${ }^{84}$ Green spaces are known to alleviate exposure to harmful environments, such as noise and air pollution, and can help relieve stress, making them an environmental resource for psychological recovery. ${ }^{86}$ In addition, access to green spaces can provide opportunities for social interaction. Glonti et al. ${ }^{87}$ suggested that high social bonding and cohesion are associated with a low risk of obesity.

Studies have shown that the presence of green spaces around residential areas has a positive effect on lowering obesity. A longitudinal study of people living in Finnish urban areas examined the relationship between the proximity of green spaces and BMI. Living at a distance exceeding $750 \mathrm{~m}$ compared to living at a distance less than $250 \mathrm{~m}$ from green spaces increased the incidence of overweight (odds ratio [OR], 1.50; 95\% CI, 1.07-2.11). In addition, an analysis of people who moved during the study showed that the incidence of obesity increased (OR, 1.49; 95\% CI, 1.08-2.06) when moving away from green spaces (from $<250 \mathrm{~m}$ to $>250 \mathrm{~m}$ ). ${ }^{88}$ Rundle et al. ${ }^{89}$ surveyed 13,102 people in New York City and reported that a closer distance between large parks and residences was associated with a lower BMI $(\beta,-1.69 ; 95 \% \mathrm{CI},-2.76$ to -0.63$)$, and Toftager et al..$^{90}$ reported that the incidence of obesity was higher in those living more than $1 \mathrm{~km}$ away from green spaces than in those living within $300 \mathrm{~m}$ (OR, 1.36; 95\% CI, 1.08-1.71). However, research results on the relationship between the proximity of green spaces and BMI are not always consistent. ${ }^{91}$ Luo et al. ${ }^{91}$ reviewed epidemiological studies on green spaces and overweight/obesity published before January 2020 and conducted a meta-analysis on 57 studies in seven countries. They found that $55 \%$ of the studies reviewed reported an association between green space and lower odds of overweight/obesity in overall or subpopulations.

\section{CONCLUSION}

Recent studies have suggested that the surge in obesity prevalence may be due to novel environmental factors that occur in the process of developing into a modern society. This review focused on light pollution, air pollution, EDC, and reduced greenspace (Table 1, Fig. 1), but many more unknown nontraditional risk factors for obesity might exist. The exact mechanism by which these factors contribute to obesity has not yet been fully identified, and the associations are not always consistent. However, there is ample evidence to support the fact that the environmental factors described above are associated with an increased prevalence of obesi- 
Table 1. Representative human studies on the effect of nontraditional risk factors of obesity

\begin{tabular}{|c|c|c|c|c|}
\hline Study population & No. of participants & Exposure & Main finding & Reference \\
\hline \multicolumn{5}{|l|}{ ALAN } \\
\hline $\begin{array}{l}\text { Non-obese American adults } \\
\text { (age, } 50-71 \mathrm{yr} \text { ) }\end{array}$ & 239,781 & $\begin{array}{l}\text { Outdoor light at night } \\
\text { (by satellite imagery) }\end{array}$ & $12 \%$ (Men) and 19\% (women) higher odds of obesity in the highest quintile group & 29 \\
\hline $\begin{array}{l}\text { Women in US and Puerto Rico } \\
\text { (age, 35-74 yr) }\end{array}$ & 43,722 & ALAN while sleeping & $\begin{array}{l}19 \% \text { Increase in the risk of incident obesity by ALAN exposure while sleeping } \\
17 \% \text { Increase in the risk of gaining } \geq 5 \mathrm{~kg} \text { and } 13 \% \text { increase in the risk of BMl increase } \\
\geq 10 \% \text { by sleeping with a television or a light on }\end{array}$ & 30 \\
\hline $\begin{array}{l}\text { Overweight and obese Latino } \\
\text { children (age, 8-15) }\end{array}$ & 314 & $\mathrm{PM}_{2.5}$ & $\begin{array}{l}4 \mu \mathrm{g} / \mathrm{m}^{3} \text { Difference in long-term } \mathrm{PM}_{2.5} \text { was associated with a } 3 \mathrm{~kg} / \mathrm{m}^{2} \text { higher } \mathrm{BMl} \text { and a } \\
2 \% \text { higher body fat percentage at age } 18\end{array}$ & 48 \\
\hline Chinese adults (age, 18-74 yr) & 24,845 & $\mathrm{PM}_{10}$ & $\begin{array}{l}19 \mu \mathrm{g} / \mathrm{m}^{3} \text { Increase of } \mathrm{PM}_{10} \text { was associated with increased prevalence of overweight } \\
(8 \%) \text { and obesity }(12 \%)\end{array}$ & 49 \\
\hline \multicolumn{5}{|l|}{ Reduced green space } \\
\hline Employees in Finland & 25,317 & Distance to green space & $\begin{array}{l}\text { Higher odds of overweight (OR, 1.50) in persons living }>750 \mathrm{~m} \text { vs. }<250 \mathrm{~m} \text { from a } \\
\text { usable green area } \\
\text { Higher odds of obesity }(\mathrm{OR}, 1.49) \text { when moving away from the proximity of a green area } \\
\text { (from }<250 \mathrm{~m} \text { to }>250 \mathrm{~m} \text { ) }\end{array}$ & 83 \\
\hline $\begin{array}{l}\text { Danish adults (age, } 16 \text { yr or } \\
\text { older) }\end{array}$ & 21,832 & Distance to green space & $\begin{array}{l}\text { Higher odds of obesity (OR, 1.36) in persons living more than } 1 \mathrm{~km} \text { from green space } \\
\text { than those living closer than } 300 \mathrm{~m}\end{array}$ & 85 \\
\hline
\end{tabular}

ALAN, artificial light at night; BMI, body mass index; $\mathrm{PM}$, particulate matter; $\mathrm{PM}_{2.5}$, particulate matter with a diameter of less than $2.5 \mu \mathrm{m}$; $\mathrm{PM}_{10}$, particulate matter with a diameter of $10 \mu \mathrm{m}$ or less; $\mathrm{MBP}$, monobutyl phthalate; $\mathrm{OR}$, odds ratio; MEHP, mono-2-ethylhexyl phthalate; WC, waist circumference; MEHHP, mono(2-ethyl-5-hydroxyhexyl) phthalate.

Lightpollution(artificial light)

- Circadian rhythm disruption

- Changes in feeding behavior

- Altered hormone secretion

\section{Environmental pollution (particulatematter)}

- Oxidative stress

- Inflammation

- Endoplasmic reticulum stress

\section{Reducedgreenspace}

- Decreased opportunity for exercise

- Decreased motivation for exercise

- Decreased stress relief

- Decreased social interaction
Endocrinedisruptingchemicals

- Nuclear receptor activation

- Epigenetic modification

- Increased adipogenesis

- Decreased metabolic efficiency

- Altered endogenous hormone regulation

Figure 1. Nontraditional risk factors and their proposed mechanisms for obesity.

ty. Therefore, additional studies investigating the relationship and the mechanism of underrecognized risk factors for obesity should be continued. This would be important for bending the curve of the obesity epidemic and finally reducing the personal and public 
medical and socioeconomic burden.

\section{CONFLICTS OF INTEREST}

Seung-Hwan Lee is an editorial board member of the journal, but he was not involved in the peer reviewer selection, evaluation, or decision process of this article. Otherwise, no other potential conflicts of interest relevant to this article were reported.

\section{ACKNOWLEDGMENTS}

This work was supported by grants from the National Research Foundation of Korea (NRF-2018R1D1A1B07043223) and Seoul St. Mary's Hospital, The Catholic University of Korea to SHL.

\section{AUTHOR CONTRIBUTIONS}

Study concept and design: SHL; drafting of the manuscript: $\mathrm{SJH}$; critical revision of the manuscript: SHL; obtained funding: SHL; study supervision: SHL.

\section{REFERENCES}

1. World Health Organization. Obesity and overweight: fact sheet [Internet]. Geneva: World Health Organization; 2020 [cited 2020 Apr 1]. Available from: https://www.who.int/newsroom/fact-sheets/detail/obesity-and-overweight

2. Korean Society for the Study of Obesity. Obesity fact sheet 2020. Seoul: Korean Society for the Study of Obesity; 2020.

3. Ferguson RD, Gallagher EJ, Scheinman EJ, Damouni R, LeRoith D. The epidemiology and molecular mechanisms linking obesity, diabetes, and cancer. Vitam Horm 2013;93:51-98.

4. Haines J, Neumark-Sztainer D, Wall M, Story M. Personal, behavioral, and environmental risk and protective factors for adolescent overweight. Obesity (Silver Spring) 2007;15: 2748-60.

5. Maes HH, Neale MC, Eaves LJ. Genetic and environmental factors in relative body weight and human adiposity. Behav Genet 1997;27:325-51.

6. Patke A, Young MW, Axelrod S. Molecular mechanisms and physiological importance of circadian rhythms. Nat Rev Mol Cell Biol 2020;21:67-84.

7. Tholin S, Rasmussen F, Tynelius P, Karlsson J. Genetic and environmental influences on eating behavior: the Swedish Young Male Twins Study. Am J Clin Nutr 2005;81:564-9.

8. Chatterjee A, Lamaze A, De J, Mena W, Chélot E, Martin B, et al. Reconfiguration of a multi-oscillator network by light in the drosophila circadian clock. Curr Biol 2018;28:2007-17.e4.

9. Chen S, Feng M, Zhang S, Dong Z, Wang Y, Zhang W, et al. Angptl8 mediates food-driven resetting of hepatic circadian clock in mice. Nat Commun 2019;10:3518.

10. Hor CN, Yeung J, Jan M, Emmenegger Y, Hubbard J, Xenarios I, et al. Sleep-wake-driven and circadian contributions to daily rhythms in gene expression and chromatin accessibility in the murine cortex. Proc Natl Acad Sci U S A 2019;116: 25773-83.

11. Daut RA, Hartsock MJ, Tomczik AC, Watkins LR, Spencer RL, Maier SF, et al. Circadian misalignment has differential effects on affective behavior following exposure to controllable or uncontrollable stress. Behav Brain Res 2019;359:440-5.

12. Kuehn BM. Resetting the circadian clock might boost metabolic health. JAMA 2017;317:1303-5.

13. Padilla SL, Perez JG, Ben-Hamo M, Johnson CW, Sanchez RE, Bussi IL, et al. Kisspeptin neurons in the arcuate nucleus of the hypothalamus orchestrate circadian rhythms and metabolism. Curr Biol 2019;29:592-604.e4.

14. Wu T, Yang L, Jiang J, Ni Y, Zhu J, Zheng X, et al. Chronic glucocorticoid treatment induced circadian clock disorder leads to lipid metabolism and gut microbiota alterations in rats. Life Sci 2018;192:173-82.

15. Yin J, Li Y, Han H, Chen S, Gao J, Liu G, et al. Melatonin reprogramming of gut microbiota improves lipid dysmetabolism in high-fat diet-fed mice. J Pineal Res 2018;65:e12524.

16. Sánchez-Bretaño A, Baba K, Janjua U, Piano I, Gargini C, Tosini G. Melatonin partially protects $661 \mathrm{~W}$ cells from $\mathrm{H} 2 \mathrm{O} 2-$ induced death by inhibiting Fas/FasL-caspase-3. Mol Vis 2017; 23:844-52.

17. Contreras-Alcantara S, Baba K, Tosini G. Removal of melatonin receptor type 1 induces insulin resistance in the mouse. Obesity (Silver Spring) 2010;18:1861-3. 
18. Buonfiglio D, Tchio C, Furigo I, Donato J Jr, Baba K, CipollaNeto J, et al. Removing melatonin receptor type 1 signaling leads to selective leptin resistance in the arcuate nucleus. J Pineal Res 2019;67:e12580.

19. Kalsbeek A, Fliers E, Romijn JA, La Fleur SE, Wortel J, Bakker $\mathrm{O}$, et al. The suprachiasmatic nucleus generates the diurnal changes in plasma leptin levels. Endocrinology 2001;142: 2677-85.

20. Zhao S, Zhu Y, Schultz RD, Li N, He Z, Zhang Z, et al. Partial leptin reduction as an insulin sensitization and weight loss strategy. Cell Metab 2019;30:706-19.e6.

21. Ravussin Y, Edwin E, Gallop M, Xu L, Bartolomé A, Kraakman MJ, et al. Evidence for a non-leptin system that defends against weight gain in overfeeding. Cell Metab 2018;28:28999.e5.

22. Kettner NM, Mayo SA, Hua J, Lee C, Moore DD, Fu L. Circadian dysfunction induces leptin resistance in mice. Cell Metab 2015;22:448-59.

23. Shimba A, Cui G, Tani-Ichi S, Ogawa M, Abe S, Okazaki F, et al. Glucocorticoids drive diurnal oscillations in T cell distribution and responses by inducing interleukin-7 receptor and CXCR4. Immunity 2018;48.286-98.e6.

24. Harvey I, Stephenson EJ, Redd JR, Tran QT, Hochberg I, Qi $\mathrm{N}$, et al. Glucocorticoid-induced metabolic disturbances are exacerbated in obese male mice. Endocrinology 2018;159: 2275-87.

25. Henderson JV, Storeygard A, Weil DN. Measuring economic growth from outer space. Am Econ Rev 2012;102:994-1028.

26. Obayashi K, Saeki K, Iwamoto J, Okamoto N, Tomioka K, Nezu S, et al. Exposure to light at night, nocturnal urinary melatonin excretion, and obesity/dyslipidemia in the elderly: a cross-sectional analysis of the HEIJO-KYO study. J Clin Endocrinol Metab 2013;98:337-44.

27. Fonken LK, Aubrecht TG, Meléndez-Fernández OH, Weil ZM, Nelson RJ. Dim light at night disrupts molecular circadian rhythms and increases body weight. J Biol Rhythms 2013; 28:262-71.

28. Rybnikova NA, Haim A, Portnov BA. Does artificial light-atnight exposure contribute to the worldwide obesity pandemic? Int J Obes (Lond) 2016;40:815-23.
29. Zhang D, Jones RR, Powell-Wiley TM, Jia P, James P, Xiao Q. A large prospective investigation of outdoor light at night and obesity in the NIH-AARP Diet and Health Study. Environ Health 2020;19:74.

30. Park YM, White AJ, Jackson CL, Weinberg CR, Sandler DP. Association of exposure to artificial light at night while sleeping with risk of obesity in women. JAMA Intern Med 2019; 179:1061-71.

31. World Health Organization. Global health observatory data repository, urban outdoor air pollution: burden of disease by country [Internet]. Geneva: World Health Organization; 2008 [cited 2020 Apr 1]. Available from: https://www.who.int/ data/gho/data/themes/topics/topic-details/GHO/ambientair-pollution

32. Atkinson RW, Fuller GW, Anderson HR, Harrison RM, Armstrong B. Urban ambient particle metrics and health: a time-series analysis. Epidemiology 2010;21:501-11.

33. Wang X, Hui Y, Zhao L, Hao Y, Guo H, Ren F. Oral administration of Lactobacillus paracasei L9 attenuates PM2.5-induced enhancement of airway hyperresponsiveness and allergic airway response in murine model of asthma. PLoS One 2017; 12:e0171721.

34. Wang J, Huang J, Wang L, Chen C, Yang D, Jin M, et al. Urban particulate matter triggers lung inflammation via the ROSMAPK-NF-кB signaling pathway. J Thorac Dis 2017;9:4398412.

35. Liu CW, Lee TL, Chen YC, Liang CJ, Wang SH, Lue JH, et al. PM 2.5-induced oxidative stress increases intercellular adhesion molecule-1 expression in lung epithelial cells through the IL-6/AKT/STAT3/NF-кB-dependent pathway. Part Fibre Toxicol 2018;15:4.

36. Brook RD, Xu X, Bard RL, Dvonch JT, Morishita M, Kaciroti $\mathrm{N}$, et al. Reduced metabolic insulin sensitivity following subacute exposures to low levels of ambient fine particulate matter air pollution. Sci Total Environ 2013;448:66-71.

37. Reis MA, Carvalho A, Taborda A, Quaresma A, Dias G, Alves LC, et al. High airborne PM2.5 chlorine concentrations link to diabetes surge in Portugal. Sci Total Environ 2009;407: 5726-34.

38. Xu X, Liu C, Xu Z, Tzan K, Zhong M, Wang A, et al. Long- 
term exposure to ambient fine particulate pollution induces insulin resistance and mitochondrial alteration in adipose tissue. Toxicol Sci 2011;124:88-98.

39. Mendez R, Zheng Z, Fan Z, Rajagopalan S, Sun Q, Zhang K. Exposure to fine airborne particulate matter induces macrophage infiltration, unfolded protein response, and lipid deposition in white adipose tissue. Am J Transl Res 2013;5:224-34.

40. Thaler JP, Yi CX, Schur EA, Guyenet SJ, Hwang BH, Dietrich MO, et al. Obesity is associated with hypothalamic injury in rodents and humans. J Clin Invest 2012;122:153-62.

41. Pan WW, Myers MG Jr. Leptin and the maintenance of elevated body weight. Nat Rev Neurosci 2018;19:95-105.

42. Shi H, Kokoeva MV, Inouye K, Tzameli I, Yin H, Flier JS. TLR4 links innate immunity and fatty acid-induced insulin resistance. J Clin Invest 2006;116:3015-25.

43. Benomar Y, Taouis M. Molecular mechanisms underlying obesity-induced hypothalamic inflammation and insulin resistance. pivotal role of resistin/TLR4 pathways. Front Endocrinol (Lausanne) 2019;10:140.

44. Campolim CM, Weissmann L, Ferreira CK, Zordão OP, Dornellas AP, de Castro G, et al. Short-term exposure to air pollution (PM2.5) induces hypothalamic inflammation, and longterm leads to leptin resistance and obesity via Tlr4/Ikbke in mice. Sci Rep 2020;10:10160.

45. Wei Y, Zhang JJ, Li Z, Gow A, Chung KF, Hu M, et al. Chronic exposure to air pollution particles increases the risk of obesity and metabolic syndrome: findings from a natural experiment in Beijing. FASEB J 2016;30:2115-22.

46. Deschenes O, Wang H, Wang S, Zhang P. The effect of air pollution on body weight and obesity: evidence from China. J Dev Econ 2020;145:102461.

47. Guo Q, Xue T, Jia C, Wang B, Cao S, Zhao X, et al. Association between exposure to fine particulate matter and obesity in children: a national representative cross-sectional study in China. Environ Int 2020;143:105950.

48. Alderete TL, Habre R, Toledo-Corral CM, Berhane K, Chen $\mathrm{Z}$, Lurmann FW, et al. Longitudinal associations between ambient air pollution with insulin sensitivity, $\beta$-cell function, and adiposity in Los Angeles Latino children. Diabetes 2017; 66:1789-96.
49. Li M, Qian Z, Vaughn M, Boutwell B, Ward P, Lu T, et al. Sexspecific difference of the association between ambient air pollution and the prevalence of obesity in Chinese adults from a high pollution range area: 33 Communities Chinese Health Study. Atmos Environ 2015;117:227-33.

50. An R, Ji M, Yan H, Guan C. Impact of ambient air pollution on obesity: a systematic review. Int J Obes (Lond) 2018;42: 1112-26.

51. Pigeyre M, Yazdi FT, Kaur Y, Meyre D. Recent progress in genetics, epigenetics and metagenomics unveils the pathophysiology of human obesity. Clin Sci (Lond) 2016;130:943-86.

52. Stel J, Legler J. The role of epigenetics in the latent effects of early life exposure to obesogenic endocrine disrupting chemicals. Endocrinology 2015;156:3466-72.

53. Heindel JJ, Schug TT. The obesogen hypothesis: current status and implications for human health. Curr Environ Health Rep 2014;1:333-40.

54. Janesick AS, Blumberg B. Obesogens: an emerging threat to public health. Am J Obstet Gynecol 2016;214:559-65.

55. Grün F, Blumberg B. Environmental obesogens: organotins and endocrine disruption via nuclear receptor signaling. Endocrinology 2006;147(6 Suppl):S50-5.

56. Bergman Å, Heindel JJ, Jobling S, Kidd KA, Zoeller RT. State of the science of endocrine disrupting chemicals-2012. Geneva: World Health Organization; 2013.

57. Diamanti-Kandarakis E, Bourguignon JP, Giudice LC, Hauser R, Prins GS, Soto AM, et al. Endocrine-disrupting chemicals: an Endocrine Society scientific statement. Endocr Rev 2009; 30:293-342.

58. Janesick A, Blumberg B. Endocrine disrupting chemicals and the developmental programming of adipogenesis and obesity. Birth Defects Res C Embryo Today 2011;93:34-50.

59. Virtue S, Vidal-Puig A. Adipose tissue expandability, lipotoxicity and the metabolic syndrome: an allostatic perspective. Biochim Biophys Acta 2010;1801:338-49.

60. Polyzos SA, Kountouras J, Deretzi G, Zavos C, Mantzoros CS. The emerging role of endocrine disruptors in pathogenesis of insulin resistance. a concept implicating nonalcoholic fatty liver disease. Curr Mol Med 2012;12:68-82.

61. Cheikh Rouhou M, Karelis AD, St-Pierre DH, Lamontagne L. 
Adverse effects of weight loss: are persistent organic pollutants a potential culprit? Diabetes Metab 2016;42:215-23.

62. Tontonoz P, Spiegelman BM. Fat and beyond: the diverse biology of PPARgamma. Annu Rev Biochem 2008;77:289-312.

63. Hurst $\mathrm{CH}$, Waxman DJ. Activation of PPARalpha and PPARgamma by environmental phthalate monoesters. Toxicol Sci 2003;74:297-308.

64. Kanayama T, Kobayashi N, Mamiya S, Nakanishi T, Nishikawa J. Organotin compounds promote adipocyte differentiation as agonists of the peroxisome proliferator-activated receptor gamma/retinoid X receptor pathway. Mol Pharmacol 2005;67:766-74.

65. Lefterova MI, Haakonsson AK, Lazar MA, Mandrup S. PPAR $\gamma$ and the global map of adipogenesis and beyond. Trends Endocrinol Metab 2014;25:293-302.

66. Tyagi S, Gupta P, Saini AS, Kaushal C, Sharma S. The peroxisome proliferator-activated receptor: a family of nuclear receptors role in various diseases. J Adv Pharm Technol Res 2011; 2:236-40.

67. Braun JM, Smith KW, Williams PL, Calafat AM, Berry K, Ehrlich S, et al. Variability of urinary phthalate metabolite and bisphenol A concentrations before and during pregnancy. Environ Health Perspect 2012;120:739-45.

68. Park C, Lee J, Kong B, Park J, Song H, Choi K, et al. The effects of bisphenol A, benzyl butyl phthalate, and di(2-ethylhexyl) phthalate on estrogen receptor alpha in estrogen receptor-positive cells under hypoxia. Environ Pollut 2019;248: 774-81.

69. Kang JH, Kondo F, Katayama Y. Human exposure to bisphenol A. Toxicology 2006;226:79-89.

70. Rubin BS, Murray MK, Damassa DA, King JC, Soto AM. Perinatal exposure to low doses of bisphenol A affects body weight, patterns of estrous cyclicity, and plasma LH levels. Environ Health Perspect 2001;109:675-80.

71. Hugo ER, Brandebourg TD, Woo JG, Loftus J, Alexander JW, Ben-Jonathan N. Bisphenol A at environmentally relevant doses inhibits adiponectin release from human adipose tissue explants and adipocytes. Environ Health Perspect 2008;116: 1642-7.

72. Carwile JL, Michels KB. Urinary bisphenol A and obesity:
NHANES 2003-2006. Environ Res 2011;111:825-30.

73. Wormuth M, Scheringer M, Vollenweider M, Hungerbühler K. What are the sources of exposure to eight frequently used phthalic acid esters in Europeans? Risk Anal 2006;26:803-24.

74. Corton JC, Lapinskas PJ. Peroxisome proliferator-activated receptors. mediators of phthalate ester-induced effects in the male reproductive tract? Toxicol Sci 2005;83:4-17.

75. Lehrke M, Lazar MA. The many faces of PPARgamma. Cell 2005; 123:993-9.

76. Hao C, Cheng X, Xia H, Ma X. The endocrine disruptor mono-(2-ethylhexyl) phthalate promotes adipocyte differentiation and induces obesity in mice. Biosci Rep 2012;32:619-29.

77. Meeker JD, Calafat AM, Hauser R. Di(2-ethylhexyl) phthalate metabolites may alter thyroid hormone levels in men. Environ Health Perspect 2007;115:1029-34.

78. Stahlhut RW, van Wijngaarden E, Dye TD, Cook S, Swan SH. Concentrations of urinary phthalate metabolites are associated with increased waist circumference and insulin resistance in adult U.S. males. Environ Health Perspect 2007;115:876-82.

79. Hatch EE, Nelson JW, Qureshi MM, Weinberg J, Moore LL, Singer M, et al. Association of urinary phthalate metabolite concentrations with body mass index and waist circumference. a cross-sectional study of NHANES data, 1999-2002. Environ Health 2008;7:27.

80. Yaghjyan L, Sites S, Ruan Y, Chang SH. Associations of urinary phthalates with body mass index, waist circumference and serum lipids among females. National Health and Nutrition Examination Survey 1999-2004. Int J Obes (Lond) 2015; 39:994-1000.

81. Buser MC, Murray HE, Scinicariello F. Age and sex differences in childhood and adulthood obesity association with phthalates: analyses of NHANES 2007-2010. Int J Hyg Environ Health 2014;217:687-94.

82. Persson Å, Pyko A, Lind T, Bellander T, Östenson CG, Pershagen $\mathrm{G}$, et al. Urban residential greenness and adiposity. A cohort study in Stockholm County. Environ Int 2018;121(Pt 1):832-41.

83. Feng $X$, Astell-Burt T. Can green space quantity and quality help prevent postpartum weight gain? A longitudinal study. J Epidemiol Community Health 2019;73:295-302. 
84. Harding JL, Backholer K, Williams ED, Peeters A, Cameron AJ, Hare MJ, et al. Psychosocial stress is positively associated with body mass index gain over 5 years: evidence from the longitudinal AusDiab study. Obesity (Silver Spring) 2014;22: 277-86.

85. Jerrett M, McConnell R, Wolch J, Chang R, Lam C, Dunton G, et al. Traffic-related air pollution and obesity formation in children: a longitudinal, multilevel analysis. Environ Health 2014; 13:49.

86. Hartig T, Mitchell R, de Vries S, Frumkin H. Nature and health. Annu Rev Public Health 2014;35:207-28.

87. Glonti K, Mackenbach JD, Ng J, Lakerveld J, Oppert JM, Bárdos $\mathrm{H}$, et al. Psychosocial environment: definitions, measures and associations with weight status. A systematic review. Obes Rev 2016;17 Suppl 1:81-95.

88. Halonen JI, Kivimäki M, Pentti J, Stenholm S, Kawachi I,
Subramanian SV, et al. Green and blue areas as predictors of overweight and obesity in an 8-year follow-up study. Obesity (Silver Spring) 2014;22:1910-7.

89. Rundle A, Quinn J, Lovasi G, Bader MD, Yousefzadeh P, Weiss C, et al. Associations between body mass index and park proximity, size, cleanliness, and recreational facilities. Am J Health Promot 2013;27:262-9.

90. Toftager M, Ekholm O, Schipperijn J, Stigsdotter U, Bentsen P, Grønbæk M, et al. Distance to green space and physical activity. A Danish national representative survey. J Phys Act Health 2011;8:741-9.

91. Luo YN, Huang WZ, Liu XX, Markevych I, Bloom MS, Zhao T, et al. Greenspace with overweight and obesity: a systematic review and meta-analysis of epidemiological studies up to 2020. Obes Rev 2020;21:e13078. 